\title{
Chronic Bronchitis and Chronic Obstructive Pulmonary Disease
}

\author{
Victor Kim $^{1}$ and Gerard J. Criner ${ }^{1}$ \\ ${ }^{1}$ Division of Pulmonary and Critical Care Medicine, Department of Medicine, Temple University School of Medicine, Philadelphia, Pennsylvania
}

\begin{abstract}
Chronic bronchitis (CB) is a common but variable phenomenon in chronic obstructive pulmonary disease (COPD). It has numerous clinical consequences, including an accelerated decline in lung function, greater risk of the development of airflow obstruction in smokers, a predisposition to lower respiratory tract infection, higher exacerbation frequency, and worse overall mortality. CB is caused by overproduction and hypersecretion of mucus by goblet cells, which leads to worsening airflow obstruction by luminal obstruction of small airways, epithelial remodeling, and alteration of airway surface tension predisposing to collapse. Despite its clinical sequelae, little is known about the pathophysiology of $C B$ and goblet cell hyperplasia in COPD, and treatment options are limited. In addition, it is becoming increasingly apparent that in the classic COPD spectrum, with emphysema on one end and CB on the other, most patients lie somewhere in the middle. It is known now that many patients with severe emphysema can develop $C B$, and small airway pathology has been linked to worse clinical outcomes, such as increased mortality and lesser improvement in lung function after lung volume reduction surgery. However, in recent years, a greater understanding of the importance of $C B$ as a phenotype to identify patients with a beneficial response to therapy has been described. Herein we review the epidemiology of $C B$, the evidence behind its clinical consequences, the current understanding of the pathophysiology of goblet cell hyperplasia in COPD, and current therapies for CB.
\end{abstract}

Keywords: chronic obstructive pulmonary disease; chronic bronchitis; goblet cell hyperplasia; $\mathrm{N}$-acetylcysteine; roflumilast

Chronic obstructive pulmonary disease (COPD) is a common disease characterized by irreversible airflow obstruction and persistent inflammation to noxious environmental stimuli, usually cigarette smoke. It affects 12 to 16 million people in the United States and is the third leading cause of death and disease burden worldwide (1). COPD encompasses a spectrum of diseases, with chronic bronchitis (CB) at one end and emphysema at the other, with most individuals having some characteristics of both. The $\mathrm{CB}$ definition used in epidemiologic studies has been variable, but the classic definition is chronic cough and sputum production for at least 3 months per year for two consecutive years (2). CB has numerous clinical consequences, including an increased exacerbation rate, accelerated decline in lung function, worse health-related quality of life (HRQoL), and possibly increased mortality (3-6). We review the clinical phenotype of $\mathrm{CB}$, the

(Received in original form October 13, 2012; accepted in final form November 16, 2012) Funded by NHLBI grant 1K23HL094696-01A2.

Correspondence and requests for reprints should be addressed to Victor Kim, M.D., 785 Parkinson Pavilion, 3401 North Broad Street, Philadelphia, PA 19140. E-mail: victor.kim@tuhs.temple.edu

CME will be available for this article at http://ajrccm.atsjournals.org or at http:// cme.atsjournals.org

Am J Respir Crit Care Med Vol 187, Iss. 3, pp 228-237, Feb 1, 2013

Copyright $\odot 2013$ by the American Thoracic Society

Originally Published in Press as DOI: 10.1164/rccm.201210-1843CI on November 29, 2012 Internet address: www.atsjournals.org current understanding of its pathophysiology, and treatment options.

\section{EPIDEMIOLOGY}

$\mathrm{CB}$ is common in the general population. Table 1 provides an overview of the prevalence of cough and sputum production in population-based studies. $\mathrm{CB}$ is seen in 3.4 to $22.0 \%$ of adults (7-19). This wide range of prevalence estimates may be due to varying definitions of $\mathrm{CB}$ (i.e., chronic phlegm versus chronic cough and phlegm) as well as the possible inclusion of subjects with bronchiectasis, a syndrome also characterized by chronic cough and daily viscid sputum production that is associated with pathologic airway dilation and recurrent infection. Bronchiectasis has similar clinical manifestations as CB but has a distinctly different pathophysiology.

The prevalence of $\mathrm{CB}$ is higher in patients with COPD, affecting 14 to $74 \%$ of all patients with COPD $(4,6,20,21)$. In the Evaluation of COPD Longitudinally to Identify Predictive Surrogate Endpoints (ECLIPSE) study, 34.6\% of the 2,161 subjects reported $\mathrm{CB}$. In a 30-year longitudinal study of 1,711 Finnish men, the cumulative incidence of $\mathrm{CB}$ was $42 \%$ in continuous smokers, $26 \%$ in ex-smokers, and $22 \%$ in never smokers (22). $\mathrm{CB}$ affects approximately 10 million individuals in the United States, and the majority are between 44 and 65 years of age (23). Some $24.3 \%$ of individuals with CB are older than 65 years, and, surprisingly, $31.2 \%$ are between the ages of 18 and 44 years.

Many studies have found that $\mathrm{CB}$ affects men more than women $(6,21,24-26)$. One study in 290 American subjects with CB and Global Initiative for Chronic Obstructive Lung Disease (GOLD) stage 2 to 4 disease reported that $57 \%$ were men (6). Another study in 1,668 Chinese patients found that male sex was independently associated with the presence of CB and COPD (25). However, according to the 2009 National Center for Health Statistics report, $67.8 \%$ of patients with CB were women (23). Another study in South African patients similarly reported that females predominated the CB population (27). A 10-year study of 21,130 Danish patients showed that the cumulative prevalence of chronic mucus secretion was $10.7 \%$ in women versus $8.7 \%$ in men (18). The reasons for the higher prevalence of $\mathrm{CB}$ in women compared with men is unclear, but may be due to hormonal influences, sex differences in symptom reporting, and sex diagnostic bias; for example, in the EUROSCOP (European Respiratory Society Study on Chronic Obstructive Pulmonary Disease) study, women reported more dyspnea and cough but less phlegm symptoms than men (28). In addition, several studies have found that men were more commonly diagnosed with COPD compared with women (29).

The primary risk factor for $\mathrm{CB}$ is smoking. As mentioned earlier, the cumulative 30-year incidence of $\mathrm{CB}$ in current smokers is $42 \%$ (22). However, it should be noted that CB has been described in 4 to $22 \%$ of never smokers $(15,22)$, suggesting that other risk factors may exist. Other potential risk factors include inhalational exposures to biomass fuels, dusts, and chemical fumes 
TABLE 1. OVERVIEW OF THE PREVALENCE OF CHRONIC BRONCHITIS IN POPULATION-BASED STUDIES

\begin{tabular}{|c|c|c|}
\hline Study & Subjects & Findings \\
\hline Lange et al., 1989 (7) & General population, Copenhagen; 12,698 adults & Bronchial hypersecretion: $10.1 \%$ \\
\hline \multirow[t]{3}{*}{ Sobradillo et al., 1999 (9) } & \multirow[t]{3}{*}{ General population, Spain; 4,035 adults aged $40-69 \mathrm{yr}$} & Cough: $13.5 \%$ \\
\hline & & Expectoration: $10.7 \%$ \\
\hline & & Chronic bronchitis: $4.8 \%$ \\
\hline Pallasaho et al., 1999 (8) & Random sample, Finland; 8,000 subjects aged 20-69 yr & Productive cough: $27 \%$ \\
\hline von Hertzen et al., 2000 (10) & Random subjects, Finland; 7,217 subjects aged >30 yr & Chronic bronchitis and/or emphysema: $22 \%$ in men, $7 \%$ in women \\
\hline Cerveri et al., 2001 (11) & $\begin{array}{l}\text { General population, Europe; } 17,966 \text { subjects aged } \\
20-44 \mathrm{yr}\end{array}$ & Chronic bronchitis: $2.6 \%$ (range $0.7-9.7 \%$ across countries) \\
\hline Janson et al., 2001 (12) & Multinational; 18,277 subjects aged $20-48 \mathrm{yr}$ & Productive cough: $10.2 \%$ \\
\hline \multirow[t]{2}{*}{ Huchon et al., 2002 (13) } & \multirow[t]{2}{*}{ General population, France; 14,076 subjects } & Chronic bronchitis: $4.1 \%$ \\
\hline & & Chronic cough and/or expectoration: $11.7 \%$ \\
\hline Lundback et al., 2003 (14) & 5,892 Subjects from OLIN Study cohort & Chronic productive cough: $60 \%$ in subjects with COPD \\
\hline \multirow[t]{2}{*}{ Miravitlles et al., 2006 (15) } & \multirow[t]{2}{*}{ General population, Spain; 6,758 adults aged $>40 \mathrm{yr}$} & Cough: $5 \%$ in never smokers, $11 \%$ in smokers or ex-smokers \\
\hline & & Expectoration: $4 \%$ in never smokers, $11 \%$ in smokers and ex-smokers \\
\hline Pelkonen et al., 2006 (22) & Finnish cohort of 1,711 adult men aged $40-59 \mathrm{yr}$ & $\begin{array}{l}\text { Incidence of chronic productive cough: } 42 \% \text { current smokers, } \\
26 \% \text { past smokers, } 22 \% \text { never smokers }\end{array}$ \\
\hline De Marco et al., 2007 (16) & $\begin{array}{l}\text { International cohort of } 5,002 \text { subjects aged } 20-44 \mathrm{yr} \\
\text { with normal lung function }\end{array}$ & Chronic cough/phlegm production: $9.2 \%$ \\
\hline \multirow[t]{2}{*}{ Miravitlles et al., 2009 (17) } & \multirow{2}{*}{$\begin{array}{l}\text { Population-based sample, Spain; 4,274 adults aged } \\
40-80 \mathrm{yr}\end{array}$} & Chronic cough: $3.4 \%$ \\
\hline & & Chronic sputum production: $11.7 \%$ \\
\hline Harmsen et al., 2010 (18) & $\begin{array}{l}\text { Danish cohort of } 29,180 \text { (in 1994) and 21,130 (in 2004) } \\
\text { twins aged } 12-41 \mathrm{yr}\end{array}$ & $\begin{array}{l}\text { Cumulative prevalence of chronic mucus secretion over } 10 \mathrm{yr} \text { of study, } \\
10.7 \% \text { in female subjects and } 8.7 \% \text { in male subjects }\end{array}$ \\
\hline Martinez et al., 2012 (19) & $\begin{array}{l}\text { United States cohort of } 5,858 \text { adult past or previous } \\
\text { smokers without airflow obstruction }\end{array}$ & Chronic bronchitis: $34.6 \%$ \\
\hline
\end{tabular}

Adapted and modified by permission from Reference 119.

$(30,31)$. A national household survey of South African adults found occupational exposure to be a risk factor for $\mathrm{CB}$ in men (odds ratio [OR], 2.6; 95\% confidence interval [CI], 1.7-4.0) and exposure to smoky domestic fuels to be a risk factor for $\mathrm{CB}$ in women (OR, 1.9; 95\% CI, 1.4-2.6) (27). In a recent analysis of 5,858 smokers or ex-smokers without COPD, patients with CB were more likely to have been exposed to fumes at work $(76.4$ vs. $60.9 \%, P<0.001)$ or to have worked more than 1 year at a dusty job (76 vs. 57\%, $P<0.001$ ) (19). Another potential risk factor for $\mathrm{CB}$ is the presence of gastroesophageal reflux, possibly by pulmonary aspiration of refluxed gastric contents producing acid-induced injury and infection or neurally mediated reflex bronchoconstriction secondary to irritation of esophageal mucosa $(32,33)$.

\section{PATHOPHYSIOLOGY}

Mucous metaplasia, a process in which mucus is overproduced in response to inflammatory signals, is the pathologic foundation for $\mathrm{CB}$. The primary mechanisms responsible for excessive mucus in COPD are overproduction and hypersecretion by goblet cells and decreased elimination of mucus. Mucus hypersecretion develops as a consequence of cigarette smoke exposure $(34,35)$, acute and chronic viral infection (36), bacterial infection (37), or inflammatory cell activation of mucin gene transcription via activation of the epidermal growth factor receptor (37). This leads to overproduction of mucus and hypersecretion from increased degranulation by neutrophil-mediated elastase. This is compounded by difficulty in clearing secretions because of poor ciliary function, distal airway occlusion, and ineffective cough secondary to respiratory muscle weakness and reduced peak expiratory flow (37-39). Figure 1 summarizes the causes of excessive mucus in COPD.

Mucous metaplasia is seen with increased frequency in patients with COPD. In a bronchoscopy study of smokers with and without airflow obstruction, smokers had increased mucin stores in the large airways compared with healthy nonsmokers (40). Those with airflow obstruction primarily drove this observation. Saetta and colleagues found that current smokers with moderate COPD and CB had an increased number of goblet cells in the peripheral airways on surgical lung biopsies (41). In a small study of subjects with COPD, mucous metaplasia in the small airways increased as the degree of airflow obstruction worsened (42). A larger pathologic study found that a greater number of small airways were occluded by mucus as disease severity increased (38). Figure 2 demonstrates significant mucous metaplasia in a patient with severe COPD.

These pathologic changes correlate with clinical outcomes. Mucous metaplasia causes airflow obstruction by several mechanisms: increased mucus hypersecretion causes luminal occlusion (38); INCREASED
PRODUCTION

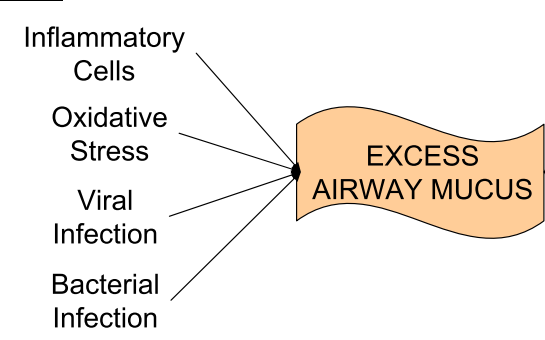

DECREASED

ELIMINATION
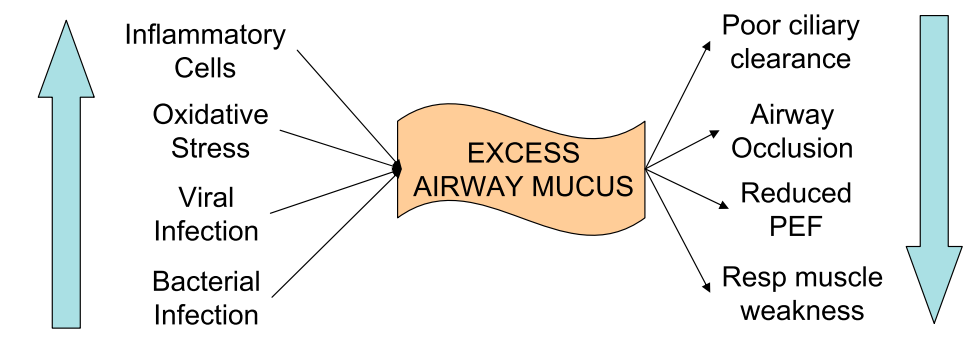

Figure 1. Causes of excessive mucus in chronic obstructive pulmonary disease. $\mathrm{PEF}=$ peak expiratory flow. 

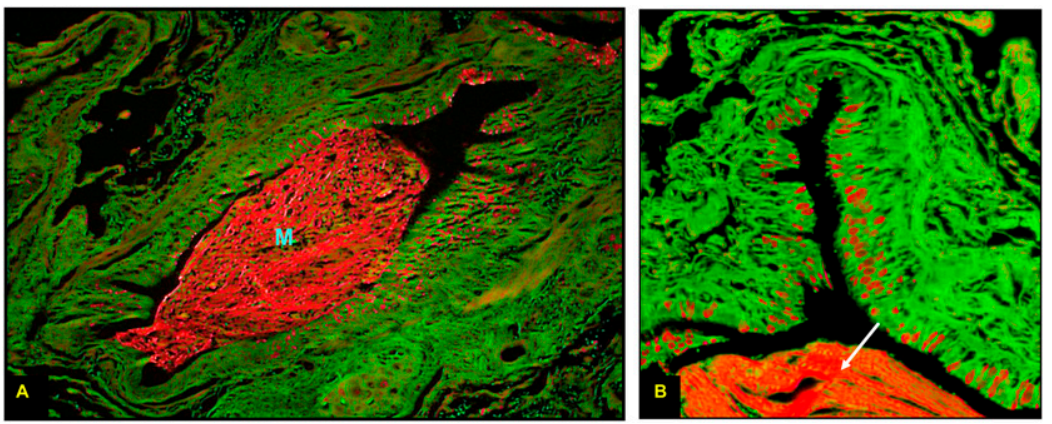

Figure 2. Periodic acid fluorescent Schiff stain of a small airway from a patient with advanced emphysema. The entire airway is seen at $\times 10$ magnification in $A$ and a quadrant of the airway at $\times 40$ in $B$. Mucin granules are shown in red along the apical border of the epithelium. Note the large intraluminal mucin plug (M) in $A$, also noted in $B$ (white arrow). Reprinted by permission from Reference 120.

epithelial layer thickening encroaches on the airway lumen (43); and increased mucus alters airway surface tension, thereby predisposing it to expiratory collapse (44). Small airway goblet cell hyperplasia negatively impacts lung function after lung volume reduction surgery (45), and small airway mucus obstruction has been associated with decreased lung volume reduction surgery postoperative survival (46).

Although it is established that the quantity of emphysema correlates well with clinical disease staging in COPD, the relationship between airway pathology, physiology, and symptom severity is weak at best. Large airway mucous metaplasia correlates poorly with the degree of airflow obstruction (47) or mucus expectoration (48). A study using the classic Reid index (ratio of submucosal mucus gland to epithelium thickness) found that inflammation weakly correlates with mucus gland volume (49). Small airway disease has been found in surgical lung specimens from those with advanced emphysema, with no clinical or radiographic evidence to suggest its presence preoperatively ( 38 , $45,50)$. More importantly, the degree of small airway mucous metaplasia is difficult to detect clinically by burden of cough or sputum (46).

The inflammatory mechanisms responsible for mucous metaplasia in COPD are poorly understood. $\mathrm{T}$ cells have been classically divided into two main populations, Th1 and Th2. Th1 cells produce cytokines such as IL- 1 , IL- 6 , and IFN- $\gamma$, whereas the cytokines produced by Th2 cells are IL-4, IL-5, and IL-13. Mucous metaplasia has been extensively described as an end product of Th2 inflammation and has been extensively studied in asthma, a disease with Th2 inflammation central to its pathophysiology $(51,52)$. However, the cellular response associated with COPD has been most frequently (although not exclusively) attributed to the inflammatory Th1 arm of the acquired immune system. Therefore, it would seem unlikely that patients with COPD would develop mucous metaplasia given the dominance of Th1 inflammation in the pathophysiology of COPD. However, recent advances in our understanding of effector $\mathrm{T}$ cell biology has revealed the existence of a second distinct subpopulation of $\mathrm{CD}^{+}{ }^{+} \mathrm{T}$ cells with particularly potent proinflammatory functional activities (53). These cells are designated Th17 cells because of their capacity to produce IL-17A and IL-17F.

There are both in vitro data and indirect clinical evidence supporting the role of Th17 inflammation in mucous metaplasia development in COPD. IL-17 is a potent inducer of IL-6 production by bronchial epithelial cells (54), and both IL-6 and IL-17 are strong inducers of Muc5AC and Muc5B, the two major airway mucins, by lung epithelial cells (55). Patients with COPD with elevated IL-6 levels in the airways are more prone to exacerbation (56), and mucus hypersecretion has been shown to be a significant risk factor for hospitalization and infection $(3,57-59)$. A recent study found an increased number of IL17 ${ }^{+}$ and $\mathrm{IL}_{2} 3^{+}$cells in the bronchial mucosa of patients with stable COPD (60). Further studies regarding the involvement of Th17 inflammation and mucous metaplasia are needed to better understand this relationship.

\section{EFFECT OF CB ON OUTCOMES}

\section{Lung Function Decline}

The presence of $\mathrm{CB}$ is associated with worsened airflow obstruction and a progressive decline in lung function. In a study that followed approximately 4,000 subjects for 12 years, those who had symptoms of CB (wheezing, cough, dyspnea, and phlegm) had a greater initial and longitudinal decline in $\mathrm{FEV}_{1}$ (57). Two large epidemiologic studies have shown that chronic mucus hypersecretion was significantly and consistently associated with both an excessive decline in $\mathrm{FEV}_{1}$ and an increased risk of COPD hospitalization $(3,5)$.

The presence of $\mathrm{CB}$ without airflow obstruction seems to predict the development of COPD. One study of an international cohort of more than 5,000 subjects 20 to 44 years old with normal lung function were followed for 11 years. Incident cases of COPD were those who had an $\mathrm{FEV}_{1} / \mathrm{FVC}$ ratio less than $70 \%$ at the end of the follow-up. Chronic cough and phlegm were independent risk factors for COPD development (incidence rate ratio, 1.85; $95 \%$ CI, 1.17-2.93), and patients with CB symptoms had a nearly threefold increased risk of developing new COPD compared with asymptomatic subjects (16). In the Obstructive Lung Disease in Northern Sweden (OLIN) study, the 7-year cumulative incidence of COPD was higher in those with cough and recurrent wheeze (61). Finally, the presence of phlegm and other respiratory symptoms in the Framingham offspring cohort identified a group that was more susceptible to develop COPD (62).

\section{Mortality}

$\mathrm{CB}$ is a risk factor for respiratory-related deaths. Prescott and colleagues found that chronic mucus hypersecretion in hospitalized patients with COPD was associated with an increased risk of death by pulmonary infection (63). Respiratory symptoms of cough and phlegm in 8,427 white U.S. adults over a 9- to 12-year observational period were associated with increased COPDrelated mortality (24). In addition, Pelkonen and colleagues found an increased risk of respiratory-related death when $\mathrm{CB}$ was present (22)

CB may increase all-cause mortality as well, independent of the level of obstructive airways disease. Table 2 summarizes selected studies that have addressed all-cause mortality. The reasons are unclear, but it has been proposed that the inflammatory state of the lung causes systemic inflammation and increases the risk of cardiac disease and other comorbidities. In the study by Pelkonen and colleagues, the multivariate hazard ratios (HRs) for all-cause mortality in those with persistent CB was 1.64 (95\% CI, 1.23-2.19) after adjustment for lung function (22). In a post hoc analysis of the National Emphysema 
TABLE 2. SUMMARY OF LONGITUDINAL STUDIES OF CHRONIC BRONCHITIS AND ALL-CAUSE MORTALITY

\begin{tabular}{llcl}
\hline Study & \multicolumn{1}{c}{ Patient Group } & Follow-up $(y r)$ & \multicolumn{1}{c}{ Risk } \\
\hline Tockman and Comstock (66) & 884 Men & 10 & OR, 1.65 for chronic phlegm (0.95-2.89) \\
Copenhagen City Heart Study (57) & 16,756 Men and women & 10 & RR, 1.1 (0.9-1.3) women, 1.3 (1.1-1.4) men \\
Pelkonen et al. (22) & 1,711 Middle-aged men & 40 & HR, 1.49(1.19-1.88) \\
Annesi and Kaufman (121) & 1,061 Men & 22 & RR, 1.35 (1.20-1.50) \\
TESAOD (5) & 1,412 Men and women & 30 & Adj HR, 2.2(1.30-3.79) for age $<50$ yr \\
NHANES I (64) & 5,542 Men and women & 22 & HR, 1.2 (0.97-1.40) \\
\hline
\end{tabular}

Definition of abbreviations: Adj = adjusted; HR = hazard ratio; NHANES = National Health and Nutrition Epidemiologic Survey; OR = odds ratio; RR = relative risk; TESAOD $=$ Tucson Epidemiologic Survey of Airway Obstructive Disease.

Treatment Trial, severe CB, defined as chronic cough, phlegm, and chest trouble, was associated with a higher mortality and hospitalization rate in those treated with medical therapy alone (64). The Tucson Epidemiological Study of Airway Obstructive Disease (TESAOD) revealed that $\mathrm{CB}$ at study enrollment significantly increased the risk of all-cause mortality in those younger than 50 years old (HR, 2.2; 95\% CI, 1.3-3.8) but not in those older than 50 years (HR, 1.0; 95\% CI, 0.7-1.3) (5). CB was also associated with higher levels of serum IL-8 and C-reactive protein, which supports the hypothesis that systemic inflammation contributes to the increased risk for mortality.

However, there are other studies that reported no significant association of $\mathrm{CB}$ with all-cause mortality. For example, the $\mathrm{Na}$ tional Health and Nutrition Epidemiologic Survey (NHANES) showed an increased mortality in those with $\mathrm{CB}$ and obstructive lung disease but not in those with CB symptoms without obstructive airways disease (65). Another study in 884 men reported only a trend for increased mortality with CB (OR, 1.65; 95\% CI, 0.95-2.89) (66). Therefore, studies to date do not show a consistent effect of $\mathrm{CB}$ on all-cause mortality, and further epidemiologic studies are warranted to clarify this relationship.

\section{COPD Exacerbation}

$\mathrm{CB}$ has also been shown to increase the risk of COPD exacerbation. Table 3 provides an overview of some critical studies that reported the clinical characteristics of patients with $\mathrm{CB}$ compared with those without CB. Seemungal and colleagues found that $\mathrm{CB}$ significantly increased the odds of having frequent exacerbations in a group of 70 patients (67). A cross-sectional analysis of 433 patients also similarly found an increased risk of exacerbation in those with $\mathrm{CB}$ compared with those without CB (4). Another cross-sectional analysis of 1,061 subjects with GOLD stage 2 to 4 disease found that those with $\mathrm{CB}$ had a greater history of exacerbations in the year before study entry $(1.21 \pm 1.62 /$ patient $/$ yr vs. $0.63 \pm 1.12 /$ patient $/ \mathrm{yr}, P=0.027)(6)$. In longitudinal follow-up of 2,997 subjects in the COPDGene cohort, those with $\mathrm{CB}$ had a $47.6 \%$ higher total exacerbation frequency than those without $\mathrm{CB}(0.93 \pm 2.11 /$ patient/yr vs. $0.63 \pm 1.69 /$ patient/yr, $P<0.0001$ ), and the adjusted HR of a frequent exacerbator phenotype (defined as more than two exacerbations per year) for CB was 1.38 (95\% CI, 1.13-1.69) (68).

\section{Health-related Quality of Life}

Finally, CB is associated with a greater burden of respiratory symptoms and worse HRQoL. In a telemedicine study of 50 patients with severe COPD with more than 14,500 observation days, those who complained of more sputum symptoms on a daily basis also complained of more dyspnea, cough, wheeze, and nasal congestion and had lower peak flow measurements (69). Compared with subjects without CB, GOLD stage 2 to 4 subjects with $\mathrm{CB}$ symptoms in the COPDGene cohort also had more severe dyspnea, more allergic nasal and ocular symptoms, more frequent nocturnal awakenings by cough and dyspnea, and worse St. George's Respiratory Questionnaire disease-specific quality of life scores (6). Similarly, worse HRQoL was noted in patients with COPD with $\mathrm{CB}$ in the COPD Clinical Research Network study of Azithromycin to Prevent COPD Exacerbations study and the PLATINO (Proyecto Latinoamericano de Investigacion

TABLE 3. SUMMARY OF CROSS-SECTIONAL STUDIES THAT COMPARED CLINICAL CHARACTERISTICS IN SUBJECTS WITH CHRONIC OBSTRUCTIVE PULMONARY DISEASE WITH AND WITHOUT CHRONIC COUGH AND SPUTUM PRODUCTION

\begin{tabular}{|c|c|c|c|c|c|c|c|c|c|c|c|}
\hline \multirow[b]{2}{*}{ Study } & \multirow[b]{2}{*}{ Population } & \multirow[b]{2}{*}{$\mathrm{n}$} & \multirow{2}{*}{$\begin{array}{l}\text { Chronic } \\
\text { Cough } \\
\text { and/or } \\
\text { Sputum }\end{array}$} & \multicolumn{2}{|c|}{ Current Smokers } & \multicolumn{2}{|c|}{ Exacerbations/Patient/yr } & \multicolumn{2}{|c|}{ Dyspnea MMRC Scale } & \multicolumn{2}{|c|}{ HRQoL } \\
\hline & & & & $\begin{array}{c}\text { Cough + } \\
\text { Sputum }\end{array}$ & $\begin{array}{c}\text { No Cough + } \\
\text { Sputum }\end{array}$ & $\begin{array}{l}\text { Cough }+ \\
\text { Sputum }\end{array}$ & $\begin{array}{c}\text { No Cough }+ \\
\text { Sputum }\end{array}$ & $\begin{array}{l}\text { Cough }+ \\
\text { Sputum }\end{array}$ & $\begin{array}{c}\text { No Cough }+ \\
\text { Sputum }\end{array}$ & $\begin{array}{l}\text { Cough + } \\
\text { Sputum }\end{array}$ & $\begin{array}{c}\text { No Cough }+ \\
\text { Sputum }\end{array}$ \\
\hline $\begin{array}{l}\text { Agusti } \\
\text { et al. (20) }\end{array}$ & $\begin{array}{l}\text { Clinic based } \\
\text { (multinational) }\end{array}$ & 2,161 & 34.6 & $\begin{array}{l}\text { GOLD 2: } 52^{\star} \\
\text { GOLD 3: } 46^{\star} \\
\text { GOLD 4: } 37^{*}\end{array}$ & $\begin{array}{l}\text { GOLD 2: } 3^{\dagger} \\
\text { GOLD 3: } 3 \\
\text { GOLD 4: } 21\end{array}$ & $\begin{array}{l}\text { GOLD 2: } 0.6 \pm 1.1 \\
\text { GOLD 3: } 1.0 \pm 1.2 \\
\text { GOLD 4: } 1.2 \pm 1.6\end{array}$ & $\begin{array}{l}\text { GOLD 2: } 0.7 \pm 1.0 \\
\text { GOLD 3: } 1.0 \pm 1.4 \\
\text { GOLD 4: } 1.2 \pm 1.3\end{array}$ & $\begin{array}{l}\text { GOLD 2: } 1.5 \pm 1.0^{*} \\
\text { GOLD 3: } 1.8 \pm 1.0 \\
\text { GOLD 4: } 2.4 \pm 1.0\end{array}$ & $\begin{array}{l}\text { GOLD 2: } 1.3 \pm 1.0 \\
\text { GOLD } 3: 1.8 \pm 1.1 \\
\text { GOLD 4: } 2.3 \pm 1.0\end{array}$ & $\begin{array}{c}\text { SGRQ-C } \\
\text { GOLD 2: } 50.3 \pm 18.8^{*} \\
\text { GOLD 3: } 58.8 \pm 17.6^{*} \\
\text { GOLD 4: } 65.0 \pm 16.5^{*}\end{array}$ & $\begin{array}{c}\text { SGRQ-C } \\
\text { GOLD 2: } 38.9 \pm 20.5 \\
\text { GOLD 3: } 51.2 \pm 18.2 \\
\text { GOLD 4: } 59.4 \pm 15.2\end{array}$ \\
\hline $\begin{array}{l}\text { Burgel } \\
\quad \text { et al. (4) }\end{array}$ & $\begin{array}{l}\text { Clinic based } \\
\text { (France) }\end{array}$ & 433 & 74.1 & $28^{*}$ & 18 & $2.2 \pm 2.2^{*}$ & $1.0 \pm 1.2$ & $N / A$ & $\mathrm{~N} / \mathrm{A}$ & $N / A$ & N/A \\
\hline $\begin{array}{l}\text { Kim } \\
\quad \text { et al. (6) }\end{array}$ & Clinic based (USA) & 1,061 & 27.3 & $48^{*}$ & 27 & $1.2 \pm 1.6^{*}$ & $0.6 \pm 1.1$ & $2(2-4)^{*}$ & $2(1-3)$ & SGRQ: $62.5 \pm 19.0^{*}$ & SGRQ $38.0 \pm 22.4$ \\
\hline $\begin{array}{l}\text { de Oca } \\
\quad \text { et al. (21) }\end{array}$ & $\begin{array}{r}\text { Population based } \\
\text { (Latin America) }\end{array}$ & 759 & $14.4^{\dagger}$ & $47^{*}$ & 32 & 5.42 & 2.66 & Present: $76^{\star}$ & Present: 47 & $\begin{array}{c}\text { SF-12 physical score } \\
44.6 \pm 1.0^{*}\end{array}$ & $\begin{array}{c}\text { SF-12 physical score } \\
49.5 \pm 0.4\end{array}$ \\
\hline Lu et al. (25) & $\begin{array}{l}\text { Population based } \\
\text { (China) }\end{array}$ & 1,668 & 30.0 & $48^{*}$ & 37 & $\mathrm{~N} / \mathrm{A}$ & $\mathrm{N} / \mathrm{A}$ & MMRC $>2: 64^{*}$ & MMRC > 2: 29 & N/A & N/A \\
\hline
\end{tabular}

Definition of abbreviations: GOLD = Global Initiative for Chronic Obstructive Lung Disease; HRQL = health-related quality of life; MMRC = Modified Medical Research

Council; N/A: not applicable; SF-12: Short Form-12 questionnaire; SGRQ = St. George's Respiratory Questionnaire; SGRQ-C = COPD version of the SGRQ.

Data presented as \%, mean \pm SD, or median (interquartile range), unless otherwise specified. Reproduced by permission from Reference 122.

* $P<0.05$.

${ }^{\dagger}$ Phlegm most days, at least $3 \mathrm{mo} / \mathrm{yr}$ for $\geqslant 2 \mathrm{yr}$. 
en Obstruccion Pulmonar) study $(21,26)$. Even subjects with nonobstructed chronic bronchitis in the COPDGene cohort indicated worse HRQoL by St. George's Respiratory Questionnaire (19).

\section{TREATMENT OPTIONS}

The main goals of therapy should target the different pathophysiologic mechanisms highlighted above:

- Reduce overproduction of mucus;

- Decrease mucus hypersecretion by controlling inflammation;

- Facilitate the elimination of mucus by increasing ciliary transport, reducing mucus tenacity, and increasing shear stress to augment mucus detachment; and

- Modify cough.

These goals can be accomplished by a number of pharmacologic and nonpharmacologic means, as detailed below. Table 4 summarizes current therapeutic options.

\section{Smoking Cessation}

Smoking cessation can improve cough in many patients with $\mathrm{CB}$ by improving mucociliary function and by decreasing goblet cell hyperplasia (70). Smoking cessation has also been shown to decrease airway injury and lower levels of mucus in exfoliated sputum tracheobronchial cells compared with those who continued to smoke (71). A large longitudinal follow-up study found that the incidence rates of $\mathrm{CB}$ were much higher in current smokers compared with ex-smokers (42 vs. 26\%) (22). Abstinence from cigarette smoke may also alter the natural history of COPD by altering the immune mechanisms leading to persistent inflammation and abnormal epithelial cell gene expression attributable to tobacco smoke (37). There is unfortunately a paucity of data regarding the effects of smoking cessation on CB symptomatology. Further studies are needed to elucidate how smoking cessation affects the severity and trajectory of $\mathrm{CB}$ in COPD.

\section{Physical Measures}

Mucus clearance is aided by maneuvers that promote coughing and increase minute ventilation, including exercise. This augments shear stresses on mucosal surfaces generated by increased airflow. It also increases humidification of the airway and regulates mucus hydration. Thus, methods such as application of positive expiratory pressure or use of flutter valves or high-frequency chest compression vests may be of value but have not been studied for use in COPD in large clinical trials. Although cystic fibrosis studies have demonstrated that chest percussion and postural drainage improve mucociliary clearance, these methods have not been well studied in the COPD patient population. Few studies have addressed chest physiotherapy or directed coughing techniques in COPD, which have shown some improvements in mucus clearance but no changes in lung function (72).

\section{Expectorants and Mucolytics}

Guaifenesin works by promoting vagally mediated increase in airway secretions (73). Although it has been shown to help with the common cold, long-term use of guaifenesin has not been shown to be of benefit in COPD or CB (74). Inhaled hypertonic saline works not only by rehydrating mucus by drawing water from epithelial cells but also by promoting cough $(75,76)$. Although this method has been proved to improve lung function in cystic fibrosis, it has only been shown in one study in COPD to improve dyspnea and exercise capacity (77). Inhaled dornase alfa hydrolyzes DNA, thereby improving lung function and decreasing exacerbation frequency in patients with cystic fibrosis, in whom airway mucus concentrations of DNA are high. However, the concentration of DNA in patients with COPD is much lower (78), and dornase alfa not only is not beneficial but it may also be harmful (79).

\section{Methylxanthines and Short-Acting $\beta$-Adrenergic Receptor Agonists}

Both methylxanthines and short-acting $\beta$-adrenergic receptor agonists (SABAs) promote mucus clearance by several mechanisms:

- Increase airway luminal diameter;

- Increase ciliary beat frequency via an increase in intracellular cyclic adenosine monophosphate levels; and

- Increase mucus hydration by stimulating airway $\mathrm{Cl}^{-}$secretion via activation of the cystic fibrosis transmembrane regulator.

This decreases mucus viscosity, allowing for easier transport by airway cilia (80-82). In animal models, short-term administration of $\beta$-agonists is associated with up-regulation of mucociliary clearance $(83,84)$. Similarly, methylxanthines improve mucociliary clearance not only via their bronchodilatory properties but also by stimulating ciliary beat frequency, augmenting airway epithelial ion transport to increase mucus hydration and promoting mucus secretion in the lower airways (85). Clinical studies of

TABLE 4. SUMMARY OF THERAPEUTIC INTERVENTIONS FOR CHRONIC BRONCHITIS

\begin{tabular}{|c|c|}
\hline Intervention & Mechanism of Action \\
\hline Smoking cessation & Improves mucociliary function, decreases goblet cell hyperplasia \\
\hline Physical measures (chest PT, HFCWO, flutter valve) & Augments shear stresses to improve mucociliary clearance \\
\hline Expectorants & Vagally mediated increase in airway secretions \\
\hline Mucolytics (hypertonic saline, dornase alpha) & Rehydration of airway mucus, hydrolysis of mucus DNA \\
\hline Methylxanthines & Improves lung function, increases ciliary beat frequency \\
\hline SABA & Improves lung function, increases ciliary beat frequency \\
\hline LABA & $\begin{array}{l}\text { Improves lung function, increases ciliary beat frequency, } \\
\text { reduces hyperinflation, improves PEF }\end{array}$ \\
\hline Anticholinergics & Improves lung function, decreases mucus secretion \\
\hline Glucocorticoids & Reduces inflammation and mucus production \\
\hline PDE-4 inhibitors & Reduces inflammation, improves lung function \\
\hline Antioxidants & Breaks down mucin polymers, reduces mucus production \\
\hline Macrolides & Reduces inflammation, reduces goblet cell secretion \\
\hline
\end{tabular}

Definition of abbreviations: HFCWO = high-frequency chest wall oscillation; LABA = long-acting $\beta$-adrenergic receptor agonist; PDE-4 = phosphodiesterase-4; PEF = peak expiratory flow; PT $=$ physiotherapy; SABA $=$ short-acting $\beta$-adrenergic receptor agonist. 
theophylline in $\mathrm{CB}$ have shown improved lung function but no consistent change in cough and sputum production $(86,87)$.

\section{Long-Acting $\beta$-Adrenergic Receptor Agonists}

The effects of long-acting $\beta$-adrenergic receptor agonists (LABAs) on mucociliary function have been attributed to their beneficial effects on lung function (87-90). LABAs also reduce hyperinflation and increase peak expiratory flow, which are essential components of effective cough (91). In vitro evidence has shown that salmeterol can stimulate ciliary beat frequency (81). Similarly, formoterol significantly improves mucociliary clearance compared with placebo in patients with bronchitis (92).

\section{Anticholinergics}

Anticholinergics, by their action on the muscarinic receptor, are believed to help mucus clearance by increasing luminal diameter and by decreasing surface and submucosal gland mucin secretion (93-95). They are also believed to facilitate cough-induced mucus clearance. However, anticholinergics may desiccate airway secretions by depleting airway surface liquid, thereby making secretions more difficult to expectorate. In vivo, the literature does not support the use of anticholinergics for the treatment of CB. Ipratropium bromide has been shown to reduce the quantity and severity of coughs in chronic bronchitics (96) but is not effective in improving mucociliary clearance in COPD (97). In a study of 470 patients with $\mathrm{FEV}_{1} 39 \%$ predicted, tiotropium improved lung function but did not affect cough symptoms (98). In another study of 39 patients with COPD, tiotropium reduced the number of coughs, but mucociliary clearance was not improved (99).

\section{Glucocorticoids}

There is in vitro evidence that glucocorticoids reduce inflammation and mucus production $(100,101)$. In a murine model of asthma, inhaled corticosteroids decrease goblet cell hyperplasia (102). Dexamethasone has also been shown to decrease epithelial mucin gene MUC5AC gene expression in human bronchial epithelial cells (103). They may also hasten mucociliary clearance (104). Inhaled corticosteroids reduce exacerbation frequency and improve quality-of-life scores in COPD (105-107). Whether inhaled corticosteroids are more beneficial in patients with $\mathrm{COPD}$ with $\mathrm{CB}$ or airway-predominant phenotypes remains to be determined.

\section{Phosphodiesterase-4 Inhibitors}

Phosphodiesterase-4 (PDE-4) inhibition decreases inflammation and promotes airway smooth-muscle relaxation by preventing the hydrolysis of cyclic adenosine monophosphate to its inactive metabolite. Cilomilast and roflumilast are highly specific secondgeneration oral PDE-4 inhibitors. A metaanalysis of 23 randomized trials of roflumilast or cilomilast compared with placebo found that treatment with a PDE-4 inhibitor only modestly increased $\mathrm{FEV}_{1}(45.59 \mathrm{ml}$; 95\% CI, 39.1-52.03) but reduced the likelihood of an exacerbation (OR, 0.78; 95\% CI, 0.72-0.85) (108). Roflumilast significantly improved prebronchodilator $\mathrm{FEV}_{1}$ and decreased the rate of moderate to severe exacerbations in a 52-week randomized trial of 3,091 patients with COPD. Compared with placebo, roflumilast decreased exacerbations by $17 \%$ (95\% CI, 8-25\%) (109). In two 24 -week trials, 933 patients with moderate to severe COPD were randomly assigned to roflumilast plus salmeterol or salmeterol alone, and 743 patients were randomly assigned to roflumilast plus tiotropium or tiotropium alone (110). The overwhelming majority of patients (78-100\%) in these trials had chronic cough and sputum production at enrollment. In both trials, roflumilast significantly improved the primary endpoint, prebronchodilator $\mathrm{FEV}_{1}$, as well as the exacerbation rate. Thus, as CB increases risk for exacerbation, PDE-4 inhibitors may play a preferential role in preventing the development of exacerbation in patients with $\mathrm{CB}$ and COPD.

\section{Antioxidants}

As oxidative stress is crucial to the pathogenesis of COPD (111), antioxidant therapy may be of benefit in COPD treatment. Thiol compounds are powerful antioxidants and include $\mathrm{N}$-acetylcysteine, $\mathrm{N}$-acystelyn, carbocysteine, erdosteine, and fudosteine. The two most extensively studied antioxidant medications for COPD are $\mathrm{N}$-acetylcysteine and carbocysteine. $\mathrm{N}$-Acetylcysteine is a precursor of L-cysteine and reduced glutathione, which reduces cellular levels of oxidative stress and production of reactive oxygen species. $N$-Acetylcysteine also reduces disulfide bonds and sulfhydryl bonds that link together mucin polymers, thereby reducing sputum viscosity. Carbocysteine is a blocked thiol derivative of L-cysteine with in vitro free-radical scavenging and antiinflammatory properties and may work on the fucose and sialic acid content in mucus (112). Recent data have shed more light on the use of these agents in COPD.

The Bronchitis Randomized on NAC Cost-Utility Study (BRONCHUS) is the largest trial of $N$-acetylcysteine use in COPD to date (113). In this multicenter study, 523 patients with a mean $\mathrm{FEV}_{1}$ of $57 \%$ predicted were randomized to $N$-acetylcysteine $600 \mathrm{mg}$ daily or placebo and followed for 3 years. Mean exacerbation rates of the subjects were 2.4 to 2.5 exacerbations/yr. Primary outcomes were yearly reduction in $\mathrm{FEV}_{1}$ and the number of exacerbations per year. There were no differences in $\mathrm{FEV}_{1}$ decline over time or HRQoL between the two groups. There was also no overall difference in the number of exacerbations. However, in post hoc analysis, those without inhaled corticosteroids (about $30 \%$ of the entire group) had a significant reduction in exacerbations with $N$-acetylcysteine compared with the placebo. The Effect of Carbocysteine on Acute Exacerbation of Chronic Obstructive Pulmonary Disease (PEACE) study randomized 709 patients with at least two exacerbations within the 2 years before enrollment to carbocysteine $500 \mathrm{mg}$ three times daily or placebo, with the primary endpoint of exacerbation rate over 1 year (114). Numbers of exacerbations per patient per year declined significantly in the carbocysteine group compared with the placebo group (1.01 [SE, 0.06]; vs. 1.35 [SE, 0.06]; risk ratio, 0.75 [95\% CI, 0.62-0.92; $P=$ $0 \cdot 004])$. There were no significant interactions between COPD severity, smoking, and use of inhaled corticosteroids and the primary endpoint.

These two studies provided conflicting results on the efficacy of antioxidants on exacerbation frequency. It has been argued that $600 \mathrm{mg}$ daily of $N$-acetylcysteine was too low a dose to see a clinical effect, as $600 \mathrm{mg}$ three times daily is used in those with idiopathic pulmonary fibrosis. In addition, in the PEACE trial, the mean $\mathrm{FEV}_{1}$ was lower (44\% predicted) and only 15 to $18 \%$ of patients were treated with inhaled corticosteroids. Therefore, perhaps antioxidant therapy is more efficacious in those with lower lung function. However, it is difficult to know the efficacy of these antioxidants in comparison with inhaled corticosteroids because of the differences in study populations.

Poole and Black performed a metaanalysis of mucolytic agents for CB or COPD (115). They included randomized, placebocontrolled studies of at least 2 months' duration. They found 28 
trials involving 7,042 participants to be methodologically acceptable for further analysis. The majority of the studies involved the use of $N$-acetylcysteine $(n=14)$ or carbocysteine $(n=4)$. Compared with placebo, there was a $21 \%$ reduction in number of exacerbations per patient with oral mucolytics (weighted mean difference, -0.04 per month; $95 \% \mathrm{CI},-0.05$ to -0.03 ). There was no overall effect on lung function or increase in adverse effects from the medications.

\section{Antibiotics}

Chronic antibiotic therapy is generally not indicated for patients with emphysema or CB. Macrolide therapy, however, has been shown to have antiinflammatory properties and may have a role in the treatment of those with CB. They have been shown to inhibit proinflammatory cytokines, decrease neutrophil burst, inhibit migration and increase apoptosis, decrease eosinophilic inflammation, increase mucociliary transport, reduce goblet cell secretion, and decrease bronchoconstriction (116). The effect of chronic macrolide therapy on COPD exacerbations was assessed in 109 patients with COPD who were randomly assigned to receive erythromycin $250 \mathrm{mg}$ or placebo twice daily for 1 year (117). The erythromycin group had significantly fewer exacerbations than the placebo group. A recent large, prospective, placebo-controlled, randomized trial on the use of azithromycin (250 mg daily for 1 year) to prevent acute exacerbations of COPD (118) showed that azithromycin was associated with a significant decrease in exacerbation frequency and an improvement in HRQoL. There was, however, no significant additional benefit of azithromycin in those with $\mathrm{CB}$ at baseline.

\section{CONCLUSIONS}

$\mathrm{CB}$ is very common in smokers and in those with COPD and is associated with an accelerated decline in lung function, a greater risk of acute exacerbations, worse respiratory symptoms, and possibly greater overall mortality. It is caused by excess mucus production, hypersecretion, and mucociliary dysfunction resulting from persistent airway inflammation. Management strategies include targeting these various pathophysiologic mechanisms. Mucolytics, though helpful in other diseases with mucus hypersecretion, remain largely unhelpful in CB associated with COPD. Both SABAs and LABAs help improve mucociliary clearance and are complemented by the action of inhaled corticosteroids. Newer evidence for the use of PDE-4 inhibitors, antioxidants, and macrolides as long-term antiinflammatory agents appears promising.

\section{Future Directions}

It is evident that $\mathrm{CB}$ has significant clinical impact in COPD. Why some smokers develop CB and others do not remains a mystery. Current therapeutic options beyond bronchodilators and inhaled corticosteroids are limited. In addition, it is not clear how smoking cessation affects the natural history of CB. Further studies are desperately needed to elucidate the underlying pathophysiology to understand the nature of this disorder. This will ultimately lead to better therapies that directly target $\mathrm{CB}$ to improve symptoms, alter the risk of exacerbations, and reduce mortality.

Author disclosures are available with the text of this article at www.atsjournals.org

\section{References}

1. Mathers CD, Bernard C, Iburg KM, Inoue M, Fat DM, Shibuya K, Stein C, Tomijima N, Xu H. Global Burden of Disease in 2002: data sources, methods and results. Geneva, Switzerland: World Health
Organization; 2003. Global Programme on Evidence for Health Policy Discussion Paper No. 54.

2. National Heart Lung and Blood Institute, National Institutes of Health. Global Initiative for Chronic Obstructive Lung Disease (GOLD) guidelines, global strategy for the diagnosis, management and prevention of chronic obstructive lung disease: NHLBI/WHO workshop report. Bethesda, MD: NIH; 2001. NIH publication 2701.

3. Vestbo J, Prescott E, Lange P. Association of chronic mucus hypersecretion with FEV1 decline and chronic obstructive pulmonary disease morbidity. Copenhagen City Heart Study Group. Am J Respir Crit Care Med 1996;153:1530-1535.

4. Burgel PR, Nesme-Meyer P, Chanez P, Caillaud D, Carre P, Perez T, Roche N, Initiatives Bronchopneumopathie Chronique Obstructive Scientific Committee. Cough and sputum production are associated with frequent exacerbations and hospitalizations in COPD subjects. Chest 2009;135:975-982.

5. Guerra S, Sherrill DL, Venker C, Ceccato CM, Halonen M, Martinez FD. Chronic bronchitis before age 50 years predicts incident airflow limitation and mortality risk. Thorax 2009;64:894-900.

6. Kim V, Han MK, Vance GB, Make BJ, Newell JD, Hokanson JE, Hersh CP, Stinson D, Silverman EK, Criner GJ; The COPDGene Investigators. The chronic bronchitic phenotype of COPD: an analysis of the COPDGene study. Chest 2011;140:626-633.

7. Lange P, Groth S, Nyboe J, Appleyard M, Mortensen J, Jensen G, Schnohr P. Chronic obstructive lung disease in Copenhagen: crosssectional epidemiological aspects. J Intern Med 1989;226:25-32.

8. Pallasaho P, Lundback B, Laspa SL, Jonsson E, Kotaniemi J, Sovijarvi AR, Laitinen LA. Increasing prevalence of asthma but not of chronic bronchitis in Finland? Report from the FinEsS-Helsinki Study. Respir Med 1999;93:798-809.

9. Sobradillo V, Miravitlles M, Jimenez CA, Gabriel R, Viejo JL, Masa JF, Fernandez-Fau L, Villasante C. Epidemiological study of chronic obstructive pulmonary disease in Spain (IBERPOC): prevalence of chronic respiratory symptoms and airflow limitation. Arch Bronconeumol 1999;35:159-166.

10. von Hertzen L, Reunanen A, Impivaara O, Malkia E, Aromaa A. Airway obstruction in relation to symptoms in chronic respiratory disease-a nationally representative population study. Respir Med 2000;94:356-363.

11. Cerveri I, Accordini S, Verlato G, Corsico A, Zoia MC, Casali L, Burney P, de Marco R; European Community Respiratory Health Survey (ECRHS) Study Group. Variations in the prevalence across countries of chronic bronchitis and smoking habits in young adults. Eur Respir J 2001;18:85-92.

12. Janson C, Chinn S, Jarvis D, Burney P. Determinants of cough in young adults participating in the European Community Respiratory Health Survey. Eur Respir J 2001;18:647-654.

13. Huchon GJ, Vergnenegre A, Neukirch F, Brami G, Roche N, Preux PM. Chronic bronchitis among French adults: high prevalence and underdiagnosis. Eur Respir J 2002;20:806-812.

14. Lundback B, Lindberg A, Lindstrom M, Ronmark E, Jonsson AC, Jonsson E, Larsson LG, Andersson S, Sandstrom T, Larsson K. Obstructive Lung Disease in Northern Sweden Studies. Not 15 but $50 \%$ of smokers develop COPD?-Report from the Obstructive Lung Disease in Northern Sweden Studies. Respir Med 2003;97:115-122.

15. Miravitlles M, de la Roza C, Morera J, Montemayor T, Gobartt E, Martin A, Alvarez-Sala JL. Chronic respiratory symptoms, spirometry and knowledge of COPD among general population. Respir Med 2006;100:1973-1980.

16. de Marco R, Accordini S, Cerveri I, Corsico A, Anto JM, Kunzli N, Janson C, Sunyer J, Jarvis D, Chinn S, et al. Incidence of chronic obstructive pulmonary disease in a cohort of young adults according to the presence of chronic cough and phlegm. Am J Respir Crit Care Med 2007;175:32-39.

17. Miravitlles M, Soriano JB, Garcia-Rio F, Munoz L, Duran-Tauleria E, Sanchez G, Sobradillo V, Ancochea J. Prevalence of COPD in Spain: impact of undiagnosed COPD on quality of life and daily life activities. Thorax 2009;64:863-868.

18. Harmsen L, Thomsen SF, Ingebrigtsen T, Steffensen IE, Skadhauge LR, Kyvik KO, Backer V. Chronic mucus hypersecretion: prevalence and risk factors in younger individuals. Int J Tuberc Lung Dis 2010;14:1052-1058. 
19. Martinez C, Chen Y, Kazerooni E, Murray S, Criner GJ, Curtis JL, Martinez FJ, Kim V, Han MK. Non-obstructive chronic bronchitis in the COPDGene cohort [abstract]. Am J Respir Crit Care Med 2012; 185:A6622.

20. Agusti A, Calverley PM, Celli B, Coxson HO, Edwards LD, Lomas DA, MacNee W, Miller BE, Rennard S, Silverman EK, et al, Evaluation of COPD Longitudinally to Identify Predictive Surrogate Endpoints (ECLIPSE) investigators. Characterisation of COPD heterogeneity in the ECLIPSE cohort. Respir Res 2010;11:122.

21. de Oca MM, Halbert RJ, Lopez MV, Perez-Padilla R, Talamo C, Moreno D, Muino A, Jardim JR, Valdivia G, Pertuze J, et al. The chronic bronchitis phenotype in subjects with and without COPD: the PLATINO study. Eur Respir J 2012;40:28-36.

22. Pelkonen M, Notkola IL, Nissinen A, Tukiainen H, Koskela H. Thirtyyear cumulative incidence of chronic bronchitis and COPD in relation to 30-year pulmonary function and 40-year mortality: a follow-up in middle-aged rural men. Chest 2006;130:1129-1137.

23. American Lung Association. Trends in COPD (chronic bronchitis and emphysema): morbidity and mortality. Washington, DC: Research and Program Services Division, Epidemiology and Statistics Unit, Americal Lung Association; 2011.

24. Speizer FE, Fay ME, Dockery DW, Ferris BG Jr. Chronic obstructive pulmonary disease mortality in six US cities. Am Rev Respir Dis 1989;140:S49-S55.

25. Lu M, Yao W, Zhong N, Zhou Y, Wang C, Chen P, Kang J, Huang S, Chen B, Wang C, et al. Chronic obstructive pulmonary disease in the absence of chronic bronchitis in China. Respirology 2010;15:1072-1078.

26. Han MK, Kim V, Martinez C, Curtis JL, Woodruff PG, Albert RK, Connett J, Criner GJ, Martinez FJ. Significance of chronic bronchitis in the COPD CRN Azithromycin in COPD Study [abstract]. Am J Respir Crit Care Med 2012;185:A3736.

27. Ehrlich RI, White N, Norman R, Laubscher R, Steyn K, Lombard C, Bradshaw D. Predictors of chronic bronchitis in South African adults. Int J Tuberc Lung Dis 2004;8:369-376.

28. Watson L, Schouten JP, Lofdahl CG, Pride NB, Laitinen LA, Postma DS; European Respiratory Society Study on Chronic Obstructive Pulmonary Disease. Predictors of COPD symptoms: does the sex of the patient matter? Eur Respir J 2006;28:311-318.

29. Chapman KR, Tashkin DP, Pye DJ. Gender bias in the diagnosis of COPD. 2001;119:1691-1695.

30. Trupin L, Earnest G, San Pedro M, Balmes JR, Eisner MD, Yelin E, Katz PP, Blanc PD. The occupational burden of chronic obstructive pulmonary disease. Eur Respir J 2003;22:462-469.

31. Matheson MC, Benke G, Raven J, Sim MR, Kromhout H, Vermeulen R, Johns DP, Walters EH, Abramson MJ. Biological dust exposure in the workplace is a risk factor for chronic obstructive pulmonary disease. Thorax 2005;60:645-651.

32. Barish CF, Wu WC, Castell DO. Respiratory complications of gastroesophageal reflux. Arch Intern Med 1985;145:1882-1888.

33. Smyrnios NA, Irwin RS, Curley FJ. Chronic cough with a history of excessive sputum production. The spectrum and frequency of causes, key components of the diagnostic evaluation, and outcome of specific therapy. Chest 1995;108:991-997.

34. Ebert RV, Terracio MJ. The bronchiolar epithelium in cigarette smokers. Observations with the scanning electron microscope. $A m$ Rev Respir Dis 1975;111:4-11.

35. Deshmukh HS, Case LM, Wesselkamper SC, Borchers MT, Martin LD Shertzer HG, Nadel JA, Leikauf GD. Metalloproteinases mediate mucin $5 \mathrm{AC}$ expression by epidermal growth factor receptor activation. Am J Respir Crit Care Med 2005;171:305-314.

36. Holtzman MJ, Tyner JW, Kim EY, Lo MS, Patel AC, Shornick LP, Agapov E, Zhang Y. Acute and chronic airway responses to viral infection: implications for asthma and chronic obstructive pulmonary disease. Proc Am Thorac Soc 2005;2:132-140.

37. Burgel PR, Nadel JA. Roles of epidermal growth factor receptor activation in epithelial cell repair and mucin production in airway epithelium. Thorax 2004;59:992-996.

38. Hogg JC, Chu F, Utokaparch S, Woods R, Elliott WM, Buzatu L, Cherniack RM, Rogers RM, Sciurba FC, Coxson HO, et al. The nature of small-airway obstruction in chronic obstructive pulmonary disease. N Engl J Med 2004;350:2645-2653.
39. Verra F, Escudier E, Lebargy F, Bernaudin JF, De Cremoux H, Bignon J. Ciliary abnormalities in bronchial epithelium of smokers, exsmokers, and nonsmokers. Am J Respir Crit Care Med 1995;151: 630-634.

40. Innes AL, Woodruff PG, Ferrando RE, Donnelly S, Dolganov GM, Lazarus SC, Fahy JV. Epithelial mucin stores are increased in the large airways of smokers with airflow obstruction. Chest 2006;130: $1102-1108$

41. Saetta M, Turato G, Baraldo S, Zanin A, Braccioni F, Mapp CE, Maestrelli P, Cavallesco G, Papi A, Fabbri LM. Goblet cell hyperplasia and epithelial inflammation in peripheral airways of smokers with both symptoms of chronic bronchitis and chronic airflow limitation. Am J Respir Crit Care Med 2000;161:1016-1021.

42. Kim V, Kelemen SE, Abuel-Haija M, Gaughan J, Sharafkhaneh A, Evans CM, Dickey BF, Solomides CC, Rogers TJ, Criner GJ. Small airway mucous metaplasia and inflammation in chronic obstructive pulmonary disease. COPD 2008;5:329-338.

43. James AL, Wenzel S. Clinical relevance of airway remodelling in airway diseases. Eur Respir J 2007;30:134-155.

44. Macklem PT, Proctor DF, Hogg JC. The stability of peripheral airways. Respir Physiol 1970;8:191-203.

45. Kim V, Criner GJ, Abdallah HY, Gaughan JP, Furukawa S, Solomides CC. Small airway morphometry and improvement in pulmonary function after lung volume reduction surgery. Am J Respir Crit Care Med 2005;171:40-47.

46. Sciurba F, Martinez FJ, Rogers RM, Make B, Criner GJ, Cherniak RM, Patel SA, Chu F, Coxson HO, Sharafkhaneh A, et al. The effect of small airway pathology on survival following lung volume reduction surgery (LVRS) [abstract]. Proc Am Thorac Soc 2006;3:A712.

47. O'Donnell RA, Richter A, Ward J, Angco G, Mehta A, Rousseau K, Swallow DM, Holgate ST, Djukanovic R, Davies DE, et al. Expression of ErbB receptors and mucins in the airways of long term current smokers. Thorax 2004;59:1032-1040.

48. Reid LM. Pathology of chronic bronchitis. Lancet 1954;266:274-278.

49. Mullen JB, Wright JL, Wiggs BR, Pare PD, Hogg JC. Reassessment of inflammation of airways in chronic bronchitis. Br Med J (Clin Res Ed) 1985;291:1235-1239.

50. Kim WD, Ling SH, Coxson HO, English JC, Yee J, Levy RD, Pare PD, Hogg JC. The association between small airway obstruction and emphysema phenotypes in COPD. Chest 2007;131:1372-1378.

51. Zhu Z, Homer RJ, Wang Z, Chen Q, Geba GP, Wang J, Zhang Y, Elias JA. Pulmonary expression of interleukin-13 causes inflammation, mucus hypersecretion, subepithelial fibrosis, physiologic abnormalities, and eotaxin production. J Clin Invest 1999;103:779-788.

52. Romagnani S. T-cell subsets (Th1 versus Th2). Ann Allergy Asthma Immunol 2000;85:9-18; quiz 18, 21.

53. Kikly K, Liu L, Na S, Sedgwick JD. The IL-23/Th(17) axis: therapeutic targets for autoimmune inflammation. Curr Opin Immunol 2006;18: $670-675$.

54. Molet S, Hamid Q, Davoine F, Nutku E, Taha R, Page N, Olivenstein R, Elias J, Chakir J. IL-17 is increased in asthmatic airways and induces human bronchial fibroblasts to produce cytokines. J Allergy Clin Immunol 2001;108:430-438.

55. Chen Y, Thai P, Zhao YH, Ho YS, DeSouza MM, Wu R. Stimulation of airway mucin gene expression by interleukin (IL)-17 through IL-6 paracrine/autocrine loop. J Biol Chem 2003;278:17036-17043.

56. Bhowmik A, Seemungal TA, Sapsford RJ, Wedzicha JA. Relation of sputum inflammatory markers to symptoms and lung function changes in COPD exacerbations. Thorax 2000;55:114-120.

57. Sherman CB, Xu X, Speizer FE, Ferris BG Jr, Weiss ST, Dockery DW. Longitudinal lung function decline in subjects with respiratory symptoms. Am Rev Respir Dis 1992;146:855-859.

58. Lange P, Nyboe J, Appleyard M, Jensen G, Schnohr P. Relation of ventilatory impairment and of chronic mucus hypersecretion to mortality from obstructive lung disease and from all causes. Thorax 1990;45:579-585.

59. Vestbo J. Epidemiological studies in mucus hypersecretion. Novartis Found Symp 2002;248:3-12; discussion 12-9, 277-282.

60. Di Stefano A, Caramori G, Gnemmi I, Contoli M, Vicari C, Capelli A, Magno F, D'Anna SE, Zanini A, Brun P, et al. T helper type 17related cytokine expression is increased in the bronchial mucosa of 
stable chronic obstructive pulmonary disease patients. Clin Exp Immunol 2009;157:316-324.

61. Lindberg A, Eriksson B, Larsson LG, Ronmark E, Sandstrom T, Lundback B. Seven-year cumulative incidence of COPD in an agestratified general population sample. Chest 2006;129:879-885.

62. Kohansal R, Martinez-Camblor P, Agusti A, Buist AS, Mannino DM, Soriano JB. The natural history of chronic airflow obstruction revisited: an analysis of the Framingham offspring cohort. Am J Respir Crit Care Med 2009;180:3-10.

63. Prescott E, Lange P, Vestbo J. Chronic mucus hypersecretion in COPD and death from pulmonary infection. Eur Respir J 1995;8:13331338.

64. Kim V, Gaughan JP, Desai P, Washko GR, Make BJ, Han MK, Martinez FJ, Criner GJ. Chronic bronchitis is associated with worse survival in advanced emphysema [abstract]. Am J Respir Crit Care Med 2012;185:A1529.

65. Mannino DM, Buist AS, Petty TL, Enright PL, Redd SC. Lung function and mortality in the United States: data from the First National Health and Nutrition Examination Survey follow up study. Thorax 2003;58:388-393.

66. Tockman MS, Comstock GW. Respiratory risk factors and mortality: longitudinal studies in Washington County, Maryland. Am Rev Respir Dis 1989;140:S56-S63.

67. Seemungal TA, Donaldson GC, Bhowmik A, Jeffries DJ, Wedzicha JA. Time course and recovery of exacerbations in patients with chronic obstructive pulmonary disease. Am J Respir Crit Care Med 2000;161:1608-1613.

68. Kim V, Make BJ, Reagan EA, Han MK, Martinez FJ, Bowler R, Silverman EK, Crapo JD, Rogers TJ, Criner GJ, et al. Chronic bronchitis predicts greater frequency and severity of COPD exacerbations in moderate to severe COPD [abstract]. Am J Respir Crit Care Med 2012;185:A3735.

69. Kim V, Garfield JL, Grabianowski CL, Krahnke JS, Gaughan JP, Jacobs MR, Criner GJ. The effect of chronic sputum production on respiratory symptoms in severe COPD. COPD 2011;8:114-120.

70. Mullen JB, Wright JL, Wiggs BR, Pare PD, Hogg JC. Structure of central airways in current smokers and ex-smokers with and without mucus hypersecretion: relationship to lung function. Thorax 1987;42: 843-848.

71. Swan GE, Hodgkin JE, Roby T, Mittman C, Jacobo N, Peters J. Reversibility of airways injury over a 12-month period following smoking cessation. Chest 1992;101:607-612.

72. van der Schans CP. Conventional chest physical therapy for obstructive lung disease. Respir Care 2007;52:1198-1206, discussion 1206-1209.

73. Rubin BK. Mucolytics, expectorants, and mucokinetic medications. Respir Care 2007;52:859-865.

74. Thomson ML, Pavia D, McNicol MW. A preliminary study of the effect of guaiphenesin on mucociliary clearance from the human lung. Thorax 1973;28:742-747.

75. Levin MH, Sullivan S, Nielson D, Yang B, Finkbeiner WE, Verkman AS. Hypertonic saline therapy in cystic fibrosis: evidence against the proposed mechanism involving aquaporins. $J$ Biol Chem 2006;281: 25803-25812.

76. Boucher RC. Cystic fibrosis: a disease of vulnerability to airway surface dehydration. Trends Mol Med 2007;13:231-240.

77. Valderramas SR, Atallah AN. Effectiveness and safety of hypertonic saline inhalation combined with exercise training in patients with chronic obstructive pulmonary disease: a randomized trial. Respir Care 2009;54:327-333.

78. Fahy JV, Steiger DJ, Liu J, Basbaum CB, Finkbeiner WE, Boushey HA. Markers of mucus secretion and DNA levels in induced sputum from asthmatic and from healthy subjects. Am Rev Respir Dis 1993; 147:1132-1137.

79. O'Donnell AE, Barker AF, Ilowite JS, Fick RB. Treatment of idiopathic bronchiectasis with aerosolized recombinant human DNase I. rhDNase Study Group. Chest 1998;113:1329-1334.

80. Tamaoki J, Kondo M, Takizawa T. Effect of cAMP on ciliary function in rabbit tracheal epithelial cells. J Appl Physiol 1989;66:1035-1039.

81. Devalia JL, Sapsford RJ, Rusznak C, Toumbis MJ, Davies RJ. The effects of salmeterol and salbutamol on ciliary beat frequency of cultured human bronchial epithelial cells, in vitro. Pulm Pharmacol 1992;5:257-263.
82. Salathe M. Effects of beta-agonists on airway epithelial cells. $J$ Allergy Clin Immunol 2002;110:S275-S281.

83. Nguyen LP, Omoluabi O, Parra S, Frieske JM, Clement C, AmmarAouchiche Z, Ho SB, Ehre C, Kesimer M, Knoll BJ, et al. Chronic exposure to beta-blockers attenuates inflammation and mucin content in a murine asthma model. Am J Respir Cell Mol Biol 2008;38: 256-262.

84. Nguyen LP, Lin R, Parra S, Omoluabi O, Hanania NA, Tuvim MJ, Knoll BJ, Dickey BF, Bond RA. Beta2-adrenoceptor signaling is required for the development of an asthma phenotype in a murine model. Proc Natl Acad Sci USA 2009;106:2435-2440.

85. Wanner A. Effects of methylxanthines on airway mucociliary function. Am J Med 1985;79:16-21.

86. Anderson G, Peel ET, Pardoe T, Jones R. Sustained-release theophylline in chronic bronchitis. Br J Dis Chest 1982;76:261-265.

87. Taylor DR, Buick B, Kinney C, Lowry RC, McDevitt DG. The efficacy of orally administered theophylline, inhaled salbutamol, and a combination of the two as chronic therapy in the management of chronic bronchitis with reversible air-flow obstruction. Am Rev Respir Dis 1985;131:747-751

88. Foster WM, Langenback EG, Bergofsky EH. Lung mucociliary function in man: interdependence of bronchial and tracheal mucus transport velocities with lung clearance in bronchial asthma and healthy subjects. Ann Occup Hyg 1982;26:227-244.

89. Jones PW, Bosh TK. Quality of life changes in COPD patients treated with salmeterol. Am J Respir Crit Care Med 1997;155:1283-1289.

90. Mahler DA, Donohue JF, Barbee RA, Goldman MD, Gross NJ, Wisniewski ME, Yancey SW, Zakes BA, Rickard KA, Anderson WH. Efficacy of salmeterol xinafoate in the treatment of COPD. Chest 1999;115:957-965.

91. van Noord JA, Aumann JL, Janssens E, Verhaert J, Smeets JJ, Mueller A, Cornelissen PJ. Effects of tiotropium with and without formoterol on airflow obstruction and resting hyperinflation in patients with COPD. Chest 2006;129:509-517.

92. Melloni B, Germouty J. The influence of a new beta agonist: formoterol on mucociliary function. Rev Mal Respir 1992;9:503-507.

93. Wine JJ, Joo NS. Submucosal glands and airway defense. Proc Am Thorac Soc 2004;1:47-53.

94. Kummer W, Lips KS, Pfeil U. The epithelial cholinergic system of the airways. Histochem Cell Biol 2008;130:219-234.

95. Bateman ED, Rennard S, Barnes PJ, Dicpinigaitis PV, Gosens R, Gross NJ, Nadel JA, Pfeifer M, Racke K, Rabe KF, et al. Alternative mechanisms for tiotropium. Pulm Pharmacol Ther 2009;22:533-542.

96. Ghafouri MA, Patil KD, Kass I. Sputum changes associated with the use of ipratropium bromide. Chest 1984;86:387-393.

97. Bennett WD, Chapman WF, Mascarella JM. The acute effect of ipratropium bromide bronchodilator therapy on cough clearance in COPD. Chest 1993;103:488-495.

98. Casaburi R, Briggs DD Jr, Donohue JF, Serby CW, Menjoge SS, Witek TJ Jr. The spirometric efficacy of once-daily dosing with tiotropium in stable COPD: a 13-week multicenter trial. The US Tiotropium Study Group. Chest 2000;118:1294-1302.

99. Hasani A, Toms N, Agnew JE, Sarno M, Harrison AJ, Dilworth P. The effect of inhaled tiotropium bromide on lung mucociliary clearance in patients with COPD. Chest 2004;125:1726-1734.

100. Hattotuwa KL, Gizycki MJ, Ansari TW, Jeffery PK, Barnes NC. The effects of inhaled fluticasone on airway inflammation in chronic obstructive pulmonary disease: a double-blind, placebo-controlled biopsy study. Am J Respir Crit Care Med 2002;165:1592-1596.

101. Innes AL, Carrington SD, Thornton DJ, Kirkham S, Rousseau K, Dougherty RH, Raymond WW, Caughey GH, Muller SJ, Fahy JV. Ex vivo sputum analysis reveals impairment of protease-dependent mucus degradation by plasma proteins in acute asthma. Am J Respir Crit Care Med 2009;180:203-210.

102. Leung SY, Eynott P, Nath P, Chung KF. Effects of ciclesonide and fluticasone propionate on allergen-induced airway inflammation and remodeling features. J Allergy Clin Immunol 2005;115:989-996.

103. Chen Y, Nickola TJ, DiFronzo NL, Colberg-Poley AM, Rose MC. Dexamethasone-mediated repression of MUC5AC gene expression in human lung epithelial cells. Am J Respir Cell Mol Biol 2006;34: 338-347. 
104. O'Riordan TG, Mao Y, Otero R, Lopez J, Sabater JR, Abraham WM Budesonide affects allergic mucociliary dysfunction. J Appl Physiol 1998;85:1086-1091.

105. Burge PS, Calverley PM, Jones PW, Spencer S, Anderson JA, Maslen TK. Randomised, double blind, placebo controlled study of fluticasone propionate in patients with moderate to severe chronic obstructive pulmonary disease: the ISOLDE trial. BMJ 2000;320:12971303.

106. Calverley P, Pauwels R, Vestbo J, Jones P, Pride N, Gulsvik A, Anderson J, Maden C. TRial of Inhaled STeroids ANd long-acting beta2 agonists study group. Combined salmeterol and fluticasone in the treatment of chronic obstructive pulmonary disease: a randomised controlled trial. Lancet 2003;361:449-456.

107. Szafranski W, Cukier A, Ramirez A, Menga G, Sansores R, Nahabedian $\mathrm{S}$, Peterson S, Olsson H. Efficacy and safety of budesonide/formoterol in the management of chronic obstructive pulmonary disease. Eur Respir J 2003;21:74-81.

108. Chong J, Poole P, Leung B, Black PN. Phosphodiesterase 4 inhibitors for chronic obstructive pulmonary disease. Cochrane Database Syst Rev 2011; (5):CD002309.

109. Calverley PM, Rabe KF, Goehring UM, Kristiansen S, Fabbri LM, Martinez FJ. M2-124 and M2-125 study groups. Roflumilast in symptomatic chronic obstructive pulmonary disease: two randomised clinical trials. Lancet 2009;374:685-694.

110. Fabbri LM, Calverley PM, Izquierdo-Alonso JL, Bundschuh DS, Brose M, Martinez FJ, Rabe KF. M2-127 and M2-128 study groups. Roflumilast in moderate-to-severe chronic obstructive pulmonary disease treated with longacting bronchodilators: two randomised clinical trials. Lancet 2009;374:695-703.

111. MacNee W. Oxidants/antioxidants and COPD. Chest 2000;117:303S$317 \mathrm{~S}$.

112. Ishibashi Y, Takayama G, Inouye Y, Taniguchi A. Carbocisteine normalizes the viscous property of mucus through regulation of fucosylated and sialylated sugar chain on airway mucins. Eur J Pharmacol 2010;641:226-228.
113. Decramer M, Rutten-van Molken M, Dekhuijzen PN, Troosters T, van Herwaarden C, Pellegrino R, van Schayck CP, Olivieri D, Del Donno M, De Backer W, et al. Effects of N-acetylcysteine on outcomes in chronic obstructive pulmonary disease (Bronchitis Randomized on NAC Cost-Utility Study, BRONCUS): a randomised placebo-controlled trial. Lancet 2005;365:1552-1560.

114. Zheng JP, Kang J, Huang SG, Chen P, Yao WZ, Yang L, Bai CX, Wang CZ, Wang C, Chen BY, et al. Effect of carbocisteine on acute exacerbation of chronic obstructive pulmonary disease (PEACE Study): a randomised placebo-controlled study. Lancet 2008;371: 2013-2018.

115. Poole P, Black PN. Mucolytic agents for chronic bronchitis or chronic obstructive pulmonary disease. Cochrane Database Syst Rev 2010; (2):CD001287.

116. Gotfried MH. Macrolides for the treatment of chronic sinusitis, asthma, and COPD. Chest 2004;125:52S-60S; quiz 60S-61S.

117. Seemungal TA, Wilkinson TM, Hurst JR, Perera WR, Sapsford RJ, Wedzicha JA. Long-term erythromycin therapy is associated with decreased chronic obstructive pulmonary disease exacerbations. Am J Respir Crit Care Med 2008;178:1139-1147.

118. Albert RK, Connett J, Bailey WC, Casaburi R, Cooper JA Jr, Criner GJ, Curtis JL, Dransfield MT, Han MK, Lazarus SC, et al., COPD Clinical Research Network. Azithromycin for prevention of exacerbations of COPD. N Engl J Med 2011;365:689-698.

119. Miravitlles M. Cough and sputum production as risk factors for poor outcomes in patients with COPD. Respir Med 2011;105:1118 1128

120. Kim V, Rogers TJ, Criner GJ. New concepts in the pathobiology of chronic obstructive pulmonary disease. Proc Am Thor Soc 2008;5: $478-485$.

121. Annesi I, Kauffmann F. Is respiratory mucus hypersecretion really an innocent disorder? A 22-year mortality survey of 1,061 working men. Am Rev Respir Dis 1986;134:688-693.

122. Burgel PR. Chronic cough and sputum production: a clinical COPD phenotype? Eur Respir J 2012;40:4-6. 